\title{
Induction of proliferative kidney disease (PKD) in rainbow trout Oncorhynchus mykiss via the bryozoan Fredericella sultana infected with Tetracapsula bryosalmonae
}

\author{
Stephen W. Feist ${ }^{1, *}$, Matt Longshaw ${ }^{1}$, Elizabeth U. Canning ${ }^{2}$, Beth Okamura ${ }^{3}$ \\ ${ }^{1}$ CEFAS Weymouth Laboratory, Barrack Road, The Nothe, Weymouth DT4 8UB, Dorset, United Kingdom \\ ${ }^{2}$ Imperial College of Science, Technology and Medicine, London SW7 2AZ, United Kingdom \\ ${ }^{3}$ School of Animal and Microbial Sciences, The University of Reading, Whiteknights, PO Box 228, Reading RG6 6AJ, \\ Berkshire, United Kingdom
}

\begin{abstract}
Proliferative kidney disease (PKD) is a serious infection of wild and farmed salmonids, affecting mainly the kidney and spleen but becoming systemic in most susceptible fish hosts. This report deals with the transmission of Tetracapsula bryosalmonae Canning, Curry, Feist, Longshaw \& Okamura 1999 from naturally infected bryozoans Fredericella sultana Blumenbach 1779 to naïve rainbow trout Oncorhynchus mykiss Walbaum 1792, thereby confirming the recent conclusion based on partial 18S rDNA sequence data that bryozoans are hosts of the myxozoan parasite T. bryosalmonae (formerly PKX organism) that causes the disease. Parasite transmission using T. bryosalmonae spores was successful by short-term exposure to disrupted bryozoans known to contain T. bryosalmonae spores and T. bryosalmonae sacs liberated from the bryozoans, and by long-term cohabitation with infected bryozoan colonies. Infection was confirmed by examination of kidney imprints, detection of the parasite in stained tissue sections, PCR using T. bryosalmonae-specific primers, and comparison of amplified 18S rDNA sequences from the bryozoans and experimentally infected fish. Transmission was not apparent, nor was PKD induced, in fish challenged by intraperitoneal injection of spores isolated from F. sultana.
\end{abstract}

KEY WORDS: Proliferative kidney disease $(\mathrm{PKD}) \cdot$ Fredericella sultana $\cdot$ Transmission $\cdot$ Tetracapsula bryosalmonae

Resale or republication not permitted without written consent of the publisher

\section{INTRODUCTION}

Research into aspects of proliferative kidney disease (PKD) in salmonids has been successful in providing information related to the pathogenesis of the disease in the fish host and in the development of the parasite within the host tissues (Kent \& Hedrick 1986, CliftonHadley et al. 1987a,b, Feist \& Bucke 1987, Hedrick et al. 1993). However, the search for the presumed definitive fish host (Hedrick et al. 1992, Kent et al. 1995,

*E-mail: s.w.feist@cefas.co.uk
Morris et al. 1999) and, until recently (see discussion below), for an infective 'spore' stage has been unsuccessful. In addition, attempts to isolate and culture the extrasporogonic stage of the parasite have only been partially successful (R. P. Hedrick \& D. Morris pers. comm.). The development and application of several diagnostic tools, including monoclonal antibodies (Adams et al. 1992, Saulnier \& de Kinkelin 1996), lectins (Castagnaro et al. 1991) and PCR (Saulnier \& de Kinkelin 1997, Kent et al. 1998), have enabled workers to detect extremely low levels of infection. In addition, they have shown that the antigenic profile of the parasite changes as it develops in the fish. Together with 
light microscopy on fresh or fixed material, the above methods have been used to search for potential fish hosts amongst wild fish populations. In particular, research has concentrated on searching for potential hosts harbouring mature myxospore stages that could be isolated and used in experiments on the transmission requirements of the parasite (Saulnier \& de Kinkelin 1997, Kent et al. 1998, Morris et al. 1999). However, until now the only method of infecting susceptible salmonids has been to expose naïve fish to water enzootic for the disease or by the artificial means of injecting infected fish tissue or blood (Clifton-Hadley et al. 1984, Kent \& Hedrick 1985, Arkush \& Hedrick 1990, Feist \& Bucke 1993).

Understanding of the transmission requirements of myxosporean parasites has progressed significantly since the pioneering discovery that an oligochaete is an obligate host in the life cycle of Myxobolus cerebralis, the causative agent of whirling disease in salmonids (Wolf \& Markiw 1984). Subsequently, the 2-host life cycle was confirmed by El-Matbouli \& Hoffman (1989). Similar life cycles have now been demonstrated for other myxosporean genera, including Hoferellus, Ceratomyxa, Myxidium and Sphaerospora (e.g. Benajiba \& Marques 1993, Troullier et al. 1996, Bartholomew et al. 1997, Molnár et al. 1999). These life cycle studies prompted surveys for actinosporean parasites in waters enzootic for PKD, in an attempt to identify the stage infectious to fish (M. Longshaw unpubl. data, D. Morris pers. comm.). However, a recent discovery (Anderson et al. 1999a,b) revealed that a parasite of bryozoans, later named Tetracapsula bryosalmonae (Canning et al. 1999), shared near identical partial 18S rDNA gene sequences with the agent of PKD (originally designated PKX by Seagrave et al. 1980). It is now evident that $T$. bryosalmonae is widely distributed. In North America, it has been found in lacustrine environments (Anderson et al. 1999a,b) and in the UK, in rivers enzootic for PKD (Longshaw et al. 1999). These findings have opened up new avenues for investigation in PKD research. Here, we report in detail the first study to test and achieve successful transmission of $T$. bryosalmonae from a bryozoan host Fredericella sultana to rainbow trout, with the induction of clinical PKD, first reported in a footnote to Canning et al. (1999).

\section{MATERIALS AND METHODS}

Sample sources. Infected colonies of the bryozoan Fredericella sultana were obtained on July 26, 1999 from a river feeding a rainbow trout farm enzootic for PKD (site B of Longshaw et al. 1999). Colonies or portions of colonies were collected together with the wil- low Salix sp. roots on which they were growing. They were transported to the laboratory in river water and, on arrival, colonies were examined for the presence of myxozoan sacs similar to those of Tetracapsula bryozoides described by Canning et al. (1996) and Okamura (1996). Sacs were released from some colonies by breaking apart the colony branches. The released sacs (Fig. 1) were then collected and maintained in sterile, de-mineralised water at $4^{\circ} \mathrm{C}$ until required. Infection trials with these sacs were initiated within $24 \mathrm{~h}$ of collection. Additionally, willow roots with attached, infected $F$. sultana colonies were used for cohabitation trials. Although willow branches supporting infected colonies were suspended in a tank with flow-through water throughout the experiment, no attempt was made to maintain the bryozoans. Finally, kidneys from 4 fish showing clinical signs of PKD (including pronounced renal hypertrophy) were used as positive controls. These fish were obtained from a fish farm which experiences annual epizootics of PKD. The site was approximately $80 \mathrm{~km}$ from the collection site for bryozoan material. The kidneys were coarsely homogenised, allowed to settle, and the supernatant was used in infection trials (Clifton-Hadley et al. 1984).

Rainbow trout Oncorhynchus mykiss were imported as eyed eggs from a site on the Isle of Man which is known to be free of PKD. The eggs were hatched and reared in the laboratory to an average weight of $18 \mathrm{~g}$ in flow-through water. The tank water was dechlorinated drinking water from boreholes and could not therefore be a source of infection. Prior to the start of the experiment, a subsample of 10 fish was used to confirm that the fish stock was not infected with Tetracapsula bryosalmonae by examination of histological sections, kidney imprints and by PCR as described below.

Experimental procedure. Ten fish were used per trial. Naïve, susceptible fish were exposed by: (1) intra-

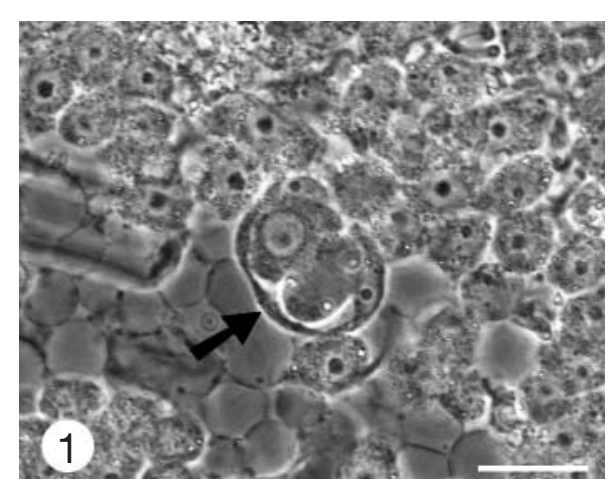

Fig. 1. Immature spore of Tetracapsula bryosalmonae (arrowed) from a ruptured parasite sac released from a Fredericella sultana zooid. Unfixed specimen. Phase contrast. Scale bar $=20 \mu \mathrm{m}$ 
peritoneal (I/P) injection with $0.2 \mathrm{ml}$ of a suspension of 20 disrupted Tetracapsula bryosalmonae sacs from Fredericella sultana in $3 \mathrm{ml}$ of distilled water; (2) exposure to disrupted bryozoans and $T$. bryosalmonae sacs in approximately $30 \mathrm{l}$ of aerated water for $90 \mathrm{~min}$ without flow-through water (short-term exposure); and (3) long-term cohabitation with infected F. sultana colonies for the duration of the experiment. Although oral gavage would have been a desirable additional route of infection, fish were not exposed by this route owing to lack of material. Additionally, control groups were established which received either no treatment or I/P injection with $0.2 \mathrm{ml}$ of sterile phosphate buffered saline (PBS) (negative controls) or I/P injection with $0.2 \mathrm{ml}$ of the supernatant of kidney homogenate from rainbow trout clinically infected with PKD (positive control group). Injection challenged fish were lightly anaesthetised with 3-aminobenzoic acid ethyl ester (MS222) solution (Sigma) prior to injection, then allowed to recover in aerated water before being placed in experimental tanks.

Exposure of fish to bryozoan material was carried out on July 27, 1999, and the positive controls were established on July 28, 1999. This was designated as Week 0. Single fish were sampled from each trial approximately every 2 wk on August 5, 1999 (Week 2), August 20, 1999 (Week 4), September 1, 1999 (Week 6), September 16, 1999 (Week 8), September 30, 1999 (Week 10), and finally the experiment was terminated on October 14, 1999 (Week 12), when the remaining fish were sacrificed for examination. Fish were maintained in $50 \mathrm{l}$ tanks with flow-through water at $16 \pm$ $0.5^{\circ} \mathrm{C}$, and held under a $12 \mathrm{~h}$ light/dark (200 lux) regime with a transition period of $30 \mathrm{~min}$ subdued lighting. Water flow rates were adjusted to give a complete exchange every $70 \mathrm{~min}$ for the duration of the trial. Fish were killed by terminal anaesthesia in MS222. At each sampling, point samples were taken for analysis by molecular biology, electron microscopy and histology.

Light microscopy. Samples of brain, gill, muscle, skin, heart, liver, kidney, spleen and gut were fixed in $10 \%$ neutral buffered formalin (NBF). Samples of skin, muscle and gill were further treated with $10 \%$ formic acid for $24 \mathrm{~h}$ and all tissues were then transferred to $70 \%$ industrial methylated spirits (IMS) and processed to wax blocks on a vacuum infiltration tissue processor. Sections were cut at $4 \mu \mathrm{m}$ and stained with haematoxylin \& eosin (H\&E). Blood smears and kidney imprints from all fish were air-dried, fixed in $0.5 \%$ acetic acid in methanol and stained with May-Grünwald Giemsa.

DNA extraction, PCR and DNA sequencing. Samples of spleen and kidney were placed in $100 \%$ ethanol. Prior to DNA extraction, samples were washed twice in
TE buffer (10 mM TRIS, 1 mM EDTA) and then soaked in TE buffer for $1 \mathrm{~h}$. Samples were lysed in $44 \mu \mathrm{l} 1 \%$ sodium dodecyl sulphate (SDS), $5 \mu$ l Proteinase K $\left(20 \mu \mathrm{ml}^{-1}\right)$ and $400 \mu \mathrm{l}$ TE buffer for $1 \mathrm{~h}$ at $60^{\circ} \mathrm{C}$. They were then extracted twice with $400 \mu \mathrm{l}$ phenol/chloroform/isoamyl alcohol (50:50:1) and $40 \mu \mathrm{l} 3 \mathrm{M}$ sodium acetate. Genomic DNA was precipitated in absolute ethanol, centrifuged at $13000 \times g$ for $15 \mathrm{~min}$ and the ethanol removed. The resultant pellet was air-dried, resuspended in $20 \mu \mathrm{l}$ of RNase/DNase-free water and stored at $-20^{\circ} \mathrm{C}$.

The myxozoan 18S rDNA was amplified by a singleround PCR using primers PKX 5F and PKX 6R (Kent et al. 1998). PCRs were performed in standard $100 \mu \mathrm{l}$ reactions containing $10 \mu \mathrm{l}$ of $10 \times$ reaction buffer IV (AB gene), $10 \mu \mathrm{l}$ of $25 \mathrm{mM}$ magnesium chloride, $0.5 \mu \mathrm{l}$ of each primer $\left(1 \mu \mathrm{g} \mathrm{ll}^{-1}\right), 1 \mu \mathrm{l}$ of Red Hot DNA polymerase $\left(5 \mathrm{U} \mathrm{ul}^{-1}\right), 1 \mu \mathrm{l}$ of $25 \mathrm{mM}$ dNTPs, $67 \mu \mathrm{l}$ of DNase/RNase-free water and $10 \mu \mathrm{l}$ of myxozoan DNA. Positive and negative controls, in the form of PKDaffected kidneys and RNase/DNase-free water respectively, were used in all amplifications. The samples were overlaid with 2 drops of mineral oil and the temperatures were cycled in a Stratagene Robocycler 40. Thirty-five cycles of $1 \mathrm{~min}$ at $94^{\circ} \mathrm{C}$, followed by $1 \mathrm{~min}$ at $55^{\circ} \mathrm{C}$, followed by $1 \mathrm{~min}$ at $72^{\circ} \mathrm{C}$ were used in the amplification. This was ended by a 5 min extension at $72^{\circ} \mathrm{C}$. PCR products were resolved for $20 \mathrm{~min}$ at $140 \mathrm{~V}$ on a $2 \%$ agarose gel containing ethidium bromide. $20 \mu \mathrm{l}$ of each $100 \mu \mathrm{l}$ reaction volume was loaded with Blue/Orange 6-loading dye (Promega). Fragment size was determined by running 5 to $10 \mu \mathrm{l}$ of a $100 \mathrm{bp}$ DNA ladder (Promega). The DNA was visualised with UV light. The DNA fragment of interest was excised from the agarose gel and separated from the agarose using the Geneclean Spin system (Bio101 Inc.) following the manufacturer's protocol. Purified PCR products were eluted in 16 to $20 \mu \mathrm{l}$ of DNase/RNase-free water and stored at $-20^{\circ} \mathrm{C}$.

PCR products were cloned into the pGEM-T Easy Vector II system (Promega). At least 2 clones with inserts for each sample were picked out using sterile toothpicks and inoculated in $10 \mathrm{ml}$ of Lennox B broth containing $100 \mu \mathrm{l}$ of $10 \mathrm{mg} \mathrm{ml}^{-1}$ ampicillin. Samples were incubated overnight at $37^{\circ} \mathrm{C}$ for 16 to $24 \mathrm{~h}$ with shaking. DNA from clones was extracted using an alkaline lysis mini preparation. Cells were lysed in $100 \mu \mathrm{l}$ of GTE solution (50 mM glucose, 10 mM EDTA, $25 \mathrm{mM}$ Tris $\mathrm{pH}$ 8.0) for $5 \mathrm{~min}$ at room temperature, followed by $200 \mu \mathrm{l}$ of $\mathrm{NaOH} / \mathrm{SDS}(0.2 \mathrm{M} \mathrm{NaOH}, 1 \% \mathrm{SDS})$ on ice for $5 \mathrm{~min}$, then $150 \mu \mathrm{l}$ of $3 \mathrm{M}$ potassium acetate solution $(60 \mathrm{ml} 5 \mathrm{M}$ potassium acetate, $11.5 \mathrm{ml}$ glacial acetic acid, $28.5 \mathrm{ml}$ DNase-free water) on ice for $5 \mathrm{~min}$. DNA was precipitated in ethanol by centrifuging at $13000 \times g$ for $20 \mathrm{~min}$. The ethanol was removed by 
vacuum suction and the pellet washed in $250 \mu \mathrm{l}$ of $70 \%$ ethanol. Pellets were air-dried, and $60 \mu$ of RNase A $\left(10 \mu \mathrm{g} \mathrm{ml}^{-1}\right)$ added. To confirm the presence of an insert, $5 \mu \mathrm{l}$ of each sample was added to $2 \mu \mathrm{l}$ of buffer II (Promega), $0.5 \mu l$ of EcoRI (Promega) and $12.5 \mu \mathrm{l}$ of water. Samples were incubated at $37^{\circ} \mathrm{C}$ for up to $1 \mathrm{~h}$ and were then run on a $2 \%$ agarose gel containing ethidium bromide at $140 \mathrm{~V}$ for $20 \mathrm{~min}$. DNA was visualised using UV light. Template DNA was cycle sequenced on a GeneAmp PCR System 9600 using the ABI Prism BigDye Terminator Cycle Sequencing Ready Reaction Kit and 3.2 pmol of either PKX 5F or PKX 6R. Extension products were purified using an ethanol/ sodium acetate precipitation and stored in Template Suppression Reagent (PE Biosystems) prior to electrophoresis on an Applied Biosystems ABI 310 Genetic Analyser.

\section{RESULTS}

Results are summarised in Table 1. Sequence information showed that there were only minor differences $(0.5 \%)$ in the $18 \mathrm{~S}$ rDNA sequence of Tetracapsula bryosalmonae obtained from Fredericella sultana and from naturally infected rainbow trout kidney material.

\section{Short-term exposure}

Extrasporogonic Tetracapsula bryosalmonae cells were detected by at least 1 method in all fish challenged by short-term exposure with the exception of the fish sampled in Week 2 and in 1 fish from Week 12 (see Table 1). No sporogonic stages were detected within renal tubules. During the short-term exposure

Table 1. Summary of results from Tetracapsula bryosalmonae transmission trials showing PCR results, presence (+) or absence (-) of parasite in renal imprints, gross clinical signs of PKD, and presence or absence of the parasite cells in stained tissue sections of liver, kidney, spleen or gills. Mort: mortalities. NE: not examined

\begin{tabular}{|c|c|c|c|c|c|c|c|c|}
\hline \multirow[t]{2}{*}{ Treatment group } & \multirow{2}{*}{$\begin{array}{c}\text { Week } \\
\text { no. }\end{array}$} & \multirow{2}{*}{ PCR } & \multirow{2}{*}{$\begin{array}{l}\text { Renal } \\
\text { Imprints }\end{array}$} & \multirow{2}{*}{$\begin{array}{l}\text { Clinical } \\
\text { PKD }\end{array}$} & \multicolumn{4}{|c|}{ Presence of $T$. bryosalmonae cells in histological sections } \\
\hline & & & & & Kidney & Spleen & Liver & Gill \\
\hline \multirow[t]{10}{*}{ Short-term exposure } & 2 & - & - & - & - & - & - & - \\
\hline & 4 & + & + & - & + & - & - & - \\
\hline & 6 & + & + & - & - & - & - & - \\
\hline & 8 & - & + & - & - & - & - & - \\
\hline & 10 & + & - & $+/-$ & + & + & - & - \\
\hline & 12 & + & + & + & - & + & + & + \\
\hline & 12 & + & + & + & + & - & - & - \\
\hline & 12 & - & - & - & - & - & - & - \\
\hline & 12 & + & + & + & + & + & - & - \\
\hline & 12 & + & - & - & - & - & - & - \\
\hline \multirow[t]{10}{*}{ Long-term cohabitation } & 2 & - & - & - & - & - & - & - \\
\hline & 4 & - & - & - & - & - & - & - \\
\hline & 6 & + & + & - & - & - & - & - \\
\hline & 8 & + & + & - & + & - & - & - \\
\hline & 10 & - & + & - & - & - & - & - \\
\hline & 12 & + & - & - & - & - & - & - \\
\hline & 12 & + & + & - & + & + & - & + \\
\hline & 12 & + & - & - & + & - & - & - \\
\hline & 12 & + & + & + & + & + & - & - \\
\hline & 12 & + & - & - & - & - & - & - \\
\hline I/P bryozoan Tetracapsula & $2-12$ & - & - & - & - & - & - & - \\
\hline \multirow[t]{10}{*}{ I/P kidney homogenate } & 2 & - & - & - & - & - & - & - \\
\hline & 4 & - & + & - & + & + & - & - \\
\hline & 6 & + & + & - & + & + & + & - \\
\hline & 8 & + & + & - & + & + & + & + \\
\hline & 10 & + & + & + & + & + & + & - \\
\hline & 12 & + & + & + & + & + & + & - \\
\hline & 12 & + & + & + & + & + & + & - \\
\hline & Mort & + & + & + & NE & NE & NE & NE \\
\hline & Mort & + & + & + & NE & NE & NE & $\mathrm{NE}$ \\
\hline & Mort & + & + & + & NE & NE & NE & $\mathrm{NE}$ \\
\hline I/P PBS & $2-12$ & - & - & - & - & - & - & - \\
\hline Negative control & $2-4$ & - & - & - & - & - & - & - \\
\hline
\end{tabular}


to disrupted bryozoans and T. bryosalmonae sacs, fish showed agitated behaviour, including twitching and flashing. This was apparent throughout the $90 \mathrm{~min}$ of exposure. These behavioural changes were not observed in other challenge fish groups (see below).

Successful amplification of a $435 \mathrm{bp}$ PCR product was achieved in fish sampled in Weeks 4,6 and 10 and in 4 of 5 fish sampled in Week 12. The nucleotide sequences obtained for the stages of Tetracapsula bryosalmonae from bryozoans and experimentally infected fish were $100 \%$ homologous.

Gross clinical signs of PKD, including exophthalmia, splenomegaly, renal hypertrophy with pale foci, gill pallor, and abdominal distension (ascites), were observed in 3 out of 5 fish sampled in Week 12. Mild renal signs of PKD were seen in the fish sampled at Week 10. Histologically, fish exhibited pathology typical of PKD with numerous parasites present in the kidney and spleen (Figs. 2, 3, 4 \& 5) and in small numbers in the liver (Fig. 6). Tetracapsula bryosalmonae cells were visible in the gill of a single fish and were associated with inflammation of the primary lamellae (Fig. 7). Inflammatory foci in the liver, spleen and heart were also noted in 2 fish sampled at Week 12. Parasites were not observed within these foci.

No blood stages of the parasite were noted in any fish from this challenge group.

\section{Long-term co-habitation}

Tetracapsula bryosalmonae was successfully transmitted to rainbow trout by long-term co-habitation with infected bryozoans. A 435 bp PCR product was amplified in fish sampled in Weeks 6 and 8 and in all 5 fish sampled in Week 12. Again, nucleotide sequence information showed $100 \%$ homology between bryozoan and fish stages. Pale foci on the kidney were observed at post mortem in a single fish sacrificed at Week 12, which also displayed frayed fins and haemorrhaging posterior to the adipose fin. Parasites were detected in all fish from Week 6 onwards by at least 1 method, and histopathological evidence of PKD was noted in samples taken at Weeks 8 and 12. Again, no blood or sporogonic stages of $T$. bryosalmonae were detected in fish from this challenge group.
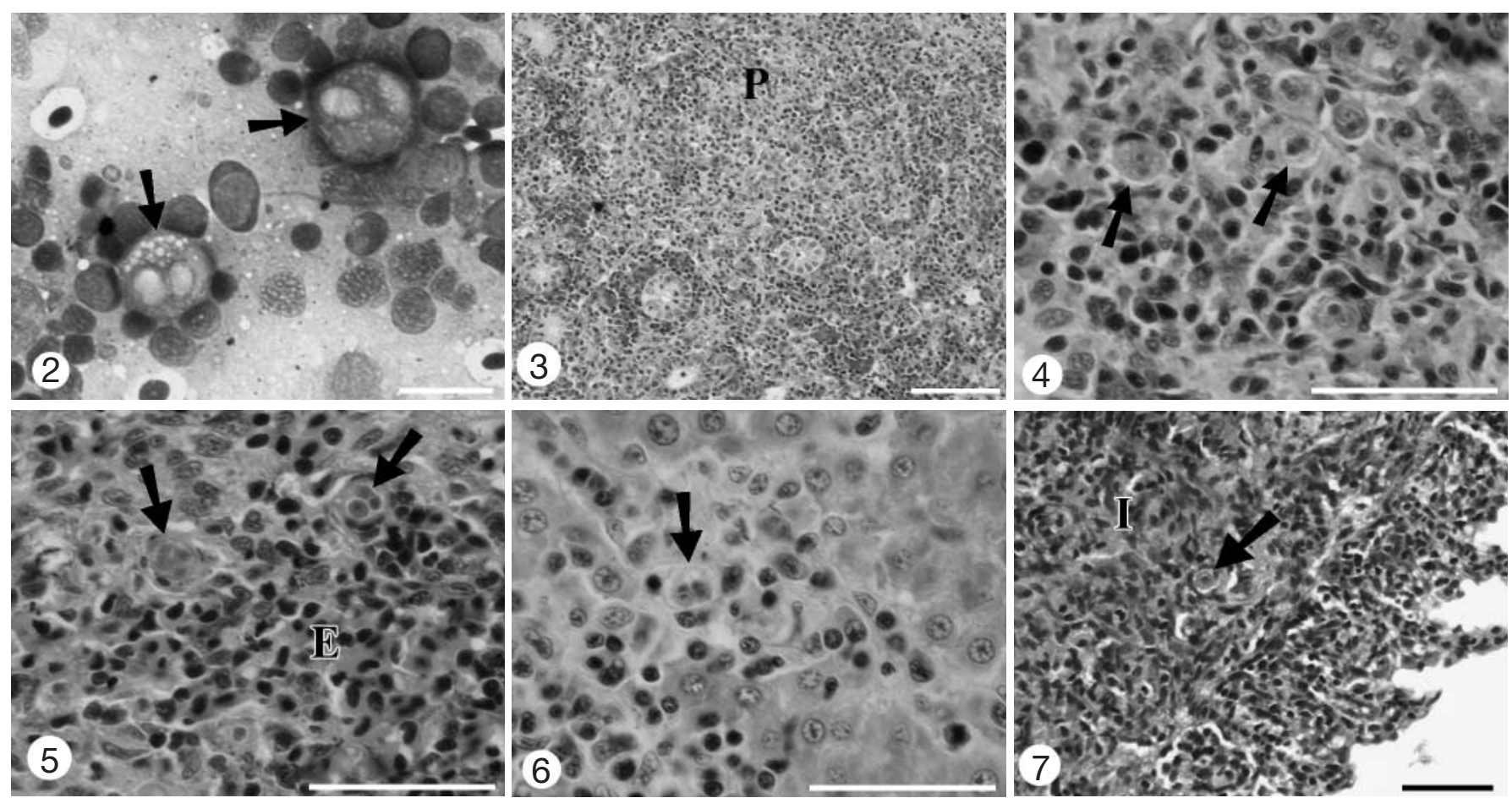

Figs. 2 to 7. Taken from rainbow trout previously exposed to infected Fredericella sultana colonies. Fig. 2. Renal imprint showing characteristic proliferative stages of Tetracapsula bryosalmonae (PKX) (arrowed) surrounded by host lymphocytes and phagocytes. May-Grünwald Giemsa. Scale bar $=20 \mu \mathrm{m}$. Fig. 3. Section of kidney exhibiting renal hypertrophy. There is a typical lack of excretory elements in areas of interstitial cell proliferation (P). Haematoxylin and eosin. Scale bar $=80 \mu \mathrm{m}$. Fig. 4. High power view of Fig. 3 with numerous $T$. bryosalmonae cells (arrowed) eliciting a vigorous inflammatory response. Haematoxylin and eosin. Scale bar $=40 \mu \mathrm{m}$. Fig. 5. Section of spleen with several $T$. bryosalmonae present (arrowed) amongst haematopoietic tissue and numerous mature erythrocytes (E). Haematoxylin and eosin. Scale bar $=40 \mu \mathrm{m}$. Fig. 6. Focal hepatic inflammation surrounding a single parasite (arrowed). Haematoxylin and eosin. Scale bar $=40 \mu \mathrm{m}$. Fig. 7. Marked branchitis with hyperplasia of the respiratory epithelium and diffuse infiltration of the primary lamellae 


\section{Intraperitoneal injection of Tetracapsula bryosalmonae spores}

Tetracapsula bryosalmonae was not transmitted nor was PKD induced in those fish that were exposed to the bryozoan parasite via I/P injection as determined from PCR, kidney imprints, blood smears and histological examination of all tissues.

\section{Positive controls (injection of PKD kidney homogenate)}

Moderate to severe renal hypertrophy was noted in all fish after and including Week 10. Typical extrasporogonic Tetracapsula bryosalmonae cells were observed in kidney imprints and histological sections in fish from Week 4 onwards. PCR results also confirmed that parasite transmission had occurred in all fish from Week 6 onwards. Induction of PKD in this group confirmed that the fish used for experimentation were susceptible to $T$. bryosalmonae. Mortalities attributed to $T$. bryosalmonae infections occurred on October 4 (2 fish) (Week 11) and on October 13, 1999 (Week 12) (confirmed by the presence of many $T$. bryosalmonae cells in kidney imprints and by PCR). Nucleotide sequence data showed $100 \%$ homology between the PCR products from fish kidneys used for challenge and the PCR products from spleen and kidney samples taken during infections that subsequently developed. No blood or sporogonic stages of $T$. bryosalmonae were detected in fish from this challenge group.

\section{Negative controls}

Tetracapsula bryosalmonae was not detected in either of the 2 negative control groups, i.e. the untreated group or those fish which had received an I/P injection with PBS. No evidence of $T$. bryosalmonae was found in these fish by PCR, histology, or examination of kidney imprints and blood smears. However, all fish in the untreated control group had died of an Aeromonas hydrophila infection by Week 6 . The bacterial infection was not encountered in any other tanks and since no mortalities occurred in the stock fish from which this group had been taken, this was considered an isolated incident.

\section{DISCUSSION}

Both short-term exposure to Tetracapsula bryosalmonae sacs and disrupted bryozoans and long-term cohabitation with bryozoans infected with $T$. bryosalmonae resulted in the successful transmission of $T$. bryosalmonae from one of its bryozoan hosts to naïve rainbow trout and subsequent induction of PKD in fish. In both trials, fish were exposed to sacs containing spores and possibly also to early proliferative stages of $T$. bryosalmonae, the bryozoans themselves, and the associated invertebrate fauna. This invertebrate fauna typically included naidid oligochaetes, dipteran larvae (especially members of the family Chironomidae), Hydra spp., Ithytrichia sp., and a wide variety of free living protists. However, through sequencing the $18 \mathrm{~S}$ rDNA of the stages in the fish and in the bryozoan hosts and by examining morphological characteristics of the parasite, we have unequivocally linked the 2 stages and confirmed the conclusions of previous molecular studies (Anderson et al. 1999a,b) that bryozoans are hosts of the causative agent of PKD. In addition, it should be noted that over 60 species of invertebrates, including representatives of the above species of associated fauna, have tested negative for $T$. bryosalmonae by PCR with $T$. bryosalmonae-specific primers (Longshaw \& Feist unpubl.). This provides evidence that the fauna associated with bryozoan colonies examined to date are not hosts of $T$. bryosalmonae.

The group of rainbow trout exposed to colonies of Fredericella sultana infected with Tetracapsula bryosalmonae may not have been exposed to $T$. bryosalmonae spores for more than a few days as no attempt was made to maintain the bryozoans, and information on their longevity under experimental conditions is lacking. It is likely that the infected colonies died under these laboratory conditions after several days, releasing $T$. bryosalmonae spores into the tank only at the beginning of the experiment. Nonetheless, clinical PKD was induced in fish in this experiment. This suggests that only a few $T$. bryosalmonae spores are needed to cause infection in susceptible fish since the spores were released in a flow-through system. This apparent efficiency in achieving infection with few spores may explain why, in field situations, morbidity of infected fish can reach $100 \%$. However, we cannot dismiss the possibility that fish may have grazed on infected F. sultana colonies and obtained a larger dose of infective stages. Gavage experiments are planned to test this possibility.

Tetracapsula bryosalmonae cells were first detected in the gills with an associated inflammatory response during Week 12 in the short-term exposed and longterm cohabited fish. Had this been the initial site of infection, it might be expected that $T$. bryosalmonae cells and pathological changes would have been apparent in the gills soon after exposure. This suggests that the primary site of infection into the fish may be elsewhere, perhaps the skin.

Injection challenge with homogenate of PKDinfected kidneys appears to be more effective at in- 
ducing an intense systemic infection than challenge by cohabitation or by short-term exposure to infective stages. One factor influencing this could be that a minimum infective dose is required in the initial stages of infection. Whirling disease has been induced in rainbow trout and brown trout that were exposed to a minimum dose of 10 Myxobolus cerebralis actinospores (Hedrick et al. 1999). Parasites injected into the peritoneal cavity as PKD-infected kidney homogenates are likely to be both numerous and adapted to conditions within the fish host. Thus, they may be more likely to induce a rapid and vigorous cellular response within the host. In contrast, parasites released from bryozoans must first gain entry into the fish host, adapt to new conditions, migrate to the target organs and tissues, and proliferate within the fish before initiating sporogony in the renal tubules. Our data indicate that when spores released by bryozoans gain entry to fish, Tetracapsula bryosalmonae can reach the kidney in $4 \mathrm{wk}$. El-Matbouli et al. (1995) showed that M. cerebralis took $21 \mathrm{~d}$ to migrate from its point of first entry into the fish to the head cartilage. During this migration, the parasite underwent several multiplications, as is known to occur in T. bryosalmonae (Kent \& Hedrick 1986).

Amplification of a 435 bp product using Tetracapsula bryosalmonae-specific primers and sequence matching of the resultant products from the pre- (bryozoan) and post- (fish) challenge stages, provided further evidence that the parasite had been transmitted. In some samples, PCR positive results were obtained, although $T$. bryosalmonae cells were not detected in imprints, smears or stained tissue sections. There are several possible explanations for this. False positives may have resulted if the primers amplified a sequence other than that of T. bryosalmonae. However, this is unlikely since the $18 \mathrm{~S}$ rDNA sequences, even for the 2 known Tetracapsula species, are about $20 \%$ dissimilar and these differ significantly from other myxozoans and from fish DNA. An apparent false positive result might have been obtained if individual fish mounted an immune response strong enough to suppress the development of the parasite, such that it could not be detected by histological methods. This is also unlikely since the naïve fish stock used is one known to be highly susceptible to the parasite. There is also a possibility that the primers were amplifying DNA from very low numbers of $T$. bryosalmonae cells, or from non-viable $T$. bryosalmonae cells, or fragments of $T$. bryosalmonae DNA. These latter explanations are reasonable possibilities since Kent et al. (1998) reported a sensitivity of $8 \mathrm{~T}$. bryosalmonae cells $\mathrm{g}^{-1}$ of fish kidney when using the primers PKX 5F and PKX 6R.

There were 3 samples that were negative by PCR but in which Tetracapsula bryosalmonae cells were visible in either tissue sections or in kidney imprints. Since the primers are very sensitive and would have detected low numbers of parasites, the negative result is surprising. The parasites observed could have been of a closely related Tetracapsula species with a different 18S rDNA sequence. However, this was regarded as unlikely since the DNA sequence of the bryozoan stage showed $100 \%$ homology with the DNA sequence in both Plumatella and Fredericella hosts examined previously (Longshaw et al. 1999). Another explanation is a possible non-uniform distribution of the parasite within the fish kidney or spleen since samples for histology or for smears were taken from slightly different parts of the organ from those used for molecular studies. It is possible that the parasite was in very low numbers or absent in the samples for molecular biology. This was also considered unlikely since examination of histological sections of the donor kidneys showed the parasite to be relatively evenly distributed. These 3 samples were re-amplified but were again negative. We are currently unable to provide an adequate explanation for this result.

In conclusion, a combination of diagnostic methods allowed the detection of successful transmission of Tetracapsula bryosalmonae from bryozoan to fish hosts, including PCR, kidney imprints and blood smears, and histology. Such a multidisciplinary approach is recommended, particularly in view of the occasional erroneous PCR results. The application of other techniques, such as serology (monoclonal antibodies), in situ hybridisation, and lectin binding, should also be considered when appropriate. Further studies to establish the routes of entry of the parasite into the fish host and the timing and early pathogenesis of the disease are in progress.

Acknowledgements. The authors would like to thank Natasha Gibson for assistance in examining bryozoans for Tetracapsula bryosalmonae infections and technical support during the infection trials, and the fish farmers, John Williams, Alasdair Watret and Andrew Mercer (Trafalgar Fisheries) and Paul Digweed (Romsey Trout Farm), for unlimited access to sites and infected fish used for trials. The work was supported by the Ministry of Agriculture Fisheries and Food (contract FC1112) (to S.W.F.) and by the Natural Environment Research Council (Grant number GR9/04271) (to B.O. and E.U.C.).

\section{LITERATURE CITED}

Adams A, Richards RH, de Mateo MM (1992) Development of monoclonal antibodies to $\mathrm{PK}^{\prime} \mathrm{X}^{\prime}$, the causative agent of proliferative kidney disease. J Fish Dis 15:515-521

Anderson CL, Canning EU, Okamura B (1999a) 18S rDNA sequences indicate that PKX organism parasitizes Bryozoa. Bull Eur Assoc Fish Pathol 19(3):94-97

Anderson CL, Canning EU, Okamura B (1999b) Molecular data implicate bryozoans as hosts for PKX (Phylum Myxozoa) and identify a clade of bryozoan parasites within the Myxozoa. Parasitology 119:555-561 
Arkush KD, Hedrick RP (1990) Experimental transmission of PKX, the causative agent of proliferative kidney disease, to three species of Pacific salmon. J Appl Ichthyol 6: 237-243

Bartholomew JL, Whipple MJ, Stevens DG, Fryer JL (1997) The life cycle of Ceratomyxa shasta, a myxosporean parasite of salmonids, requires a freshwater polychaete as an alternate host. J Parasitol 83:859-868

Benajiba MH, Marques A (1993) The alternation of actinomyxidian and myxosporidian sporal forms in the development of Myxidium giardi (parasite of Anguilla anguilla) through oligochaetes. Bull Eur Assoc Fish Pathol 13: 100-103

Canning EU, Okamura B, Curry A (1996) Development of a myxozoan parasite Tetracapsula bryozoides n.g., n.sp. in the body cavity of Cristatella mucedo (Bryozoa, Phylactolaemata). Folia Parasitol 43:249-261

Canning EU, Curry A, Feist SW, Longshaw M, Okamura B (1999) Tetracapsula bryosalmonae n. sp. for PKX organism, the cause of PKD in salmonid fish. Bull Eur Assoc Fish Pathol 19:203-206

Castagnaro M, Marin de Mateo M, Ghittino C, Hedrick RP (1991) Lectin histochemistry and ultrastructure of rainbow trout Oncorhynchus mykiss kidneys affected by proliferative kidney disease. Dis Aquat Org 10:173-183

Clifton-Hadley RS, Richards RH, Bucke D (1984) Experimental transmission of proliferative kidney disease: preliminary report. Vet Record 114:90

Clifton-Hadley RS, Bucke D, Richards RH (1987a) Proliferative kidney disease of salmonid fish: a review. J Fish Dis $7: 363-377$

Clifton-Hadley RS, Bucke D, Richards RH (1987b) A study of the sequential clinical and pathological changes during proliferative kidney disease in rainbow trout, Salmo gairdneri Richardson. J Fish Dis 10:335-352

El-Matbouli M, Hoffmann RW (1989) Experimental transmission of two Myxobolus spp. developing bisporogony via tubificid worms. Parasitol Res 75:461-464

El-Matbouli M, Hoffmann RW, Mandok C (1995) Light and electron microscopic observations on the route of the triactinomyxon-sporoplasm of Myxobolus cerebralis from the epidermis into rainbow trout cartilage. J Fish Biol 46:919-935

Feist SW, Bucke D (1987) Ultrastructural aspects of PKX, the causative agent of proliferative kidney disease in rainbow trout, Salmo gairdneri Richardson. J Fish Dis 10:323-327

Feist SW, Bucke D (1993) Proliferative kidney disease in wild salmonids. Fish Res 17:51-58

Hedrick RP, Monge D, de Kinkelin P (1992) Transmission of PKX, the causative agent of proliferative kidney disease (PKD), to rainbow trout Oncorhynchus mykiss following filtration of water and sediments. Dis Aquat Org 14: $237-240$

Hedrick RP, MacConnell E, de Kinkelin P (1993) Proliferative Kidney Disease of salmonid fish. Annu Rev Fish Dis 3: 277-290

Hedrick RP, McDowell TS, Gay M, Marty GD, Georgiadis MP, MacConnell E (1999) Comparative susceptibility of rainbow trout Oncoryhnchus mykiss and brown trout Salmo

Editorial responsibility: Wolfgang Körting,

Hannover, Germany trutta to Myxobolus cerebralis, the cause of salmonid whirling disease. Dis Aquat Org 37:173-183

Kent ML, Hedrick R (1985) Transmission of the causative agent of proliferative kidney disease (PKD) with the blood and spleen of infected fish; further evidence that the PKX parasite belongs to the phylum Myxozoa. Bull Eur Assoc Fish Pathol 5:39-42

Kent ML, Hedrick RP (1986) Development of the PKX myxosporean in rainbow trout Salmo gairdneri. Dis Aquat Org 1:169-182

Kent ML, Higgins ML, Whitaker DJ, Yokoyama H (1995) Proliferative kidney disease and Sphaerospora oncorhynchi in wild-caught salmonids from the Puntledge River system, Vancouver Island, British Columbia. Can J Fish Aquat Sci 52(Suppl 1):13-17

Kent ML Khattra J, Hervio DML, Devlin RH (1998) Ribosomal DNA sequence analysis of isolates of the PKX myxosporean and their relationship to members of the genus Sphaerospora. J Aquat Anim Health 10:12-21

Lewis PR, Knight DP (1977) Staining methods for sectioned material. In: Glauert AM (ed) Practical methods in electron microscopy. North-Holland Publishing Co, Amsterdam, p 44

Longshaw M, Feist SW, Canning EU, Okamura B (1999) First identification of PKX in bryozoans from the United Kingdom-molecular evidence. Bull Eur Assoc Fish Pathol 19(4):146-148

Molnár K, El-Mansy A, Székely Cs, Baska F (1999) Experimental identification of the actinosporean stage of Sphaerospora renicola Dykova \& Lom 1982 (Myxosporea: Sphaerosporidae) in oligochaete alternate hosts. J Fish Dis 22:143-153

Morris DJ, Longshaw M, Adams A, Feist SW, Richards RH (1999) Is an oligochaete involved in the life cycle of PKX? The British Society for Parasitology, Spring Meeting, University of Warwick, April 11-14, 1999 (Abstract)

Okamura B (1996) Occurrence, prevalence, and effects of the myxozoan Tetracapsula bryozoides Canning, Okamura and Curry, 1996, parasitic in the freshwater bryozoan Cristatella mucedo Cuvier (Bryozoa, Phylactolaemata). Folia Parasitol 43:262-266

Saulnier D, de Kinkelin P (1996) Antigenic and biochemical study of PKX, the myxosporean causative agent of proliferative kidney disease of salmonid fish. Dis Aquat Org 27:103-114

Saulnier D, de Kinkelin P (1997) Polymerase chain reaction primers for investigations on the causative agent of proliferative kidney disease of salmonids. J Fish Dis 20:467-470

Seagrave C, Bucke D, Alderman D (1980) The causative agent of proliferative kidney disease may be a member of the Haplosporidia. In: Ahne W (ed) Fish diseases Third COPRAQ-Session. Springer-Verlag, Berlin, p 174-181

Troullier A, El-Matbouli M, Hoffman RW (1996) A new look at the life-cycle of Hoferellus carassii in the goldfish (Carassius auratus auratus) and its relation to 'kidney enlargement disease' (KED). Folia Parasitol 43:173-187

Wolf K, Markiw ME (1984) Biology contravenes taxonomy in the Myxozoa: new discoveries show alternation of invertebrate and vertebrate hosts. Science 225:1449-1452

Submitted: July 31, 2000; Accepted: December 22, 2000

Proofs received from author(s): April 18, 2001 